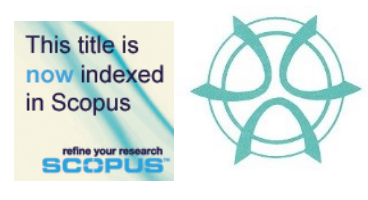

PLANNING MALAYSIA:

Journal of the Malaysian Institute of Planners

VOLUME 19 ISSUE 1 (2021), Page 150 - 161

\title{
USERS' PREFERENCES ON THE PROVISION OF FACILITIES FOR MASS RAPID TRANSIT SUNGAI BULOH - SUBANG - PUTRAJAYA LINE (MRT2) STATIONS
}

\author{
Ainina Azizan ${ }^{1}$, Mariana Mohamed Osman ${ }^{2}$, Noor Suzilawati Rabe ${ }^{3}$, \\ Nuranisa Huda Ramlan ${ }^{4}$, Nurul Ardila Azmi ${ }^{5}$ \& Suraya Amiruddin ${ }^{6}$ \\ ${ }^{1-6}$ Kulliyyah of Architecture and Environmental Design \\ INTERNATIONAL ISLAMIC UNIVERSITY MALAYSIA
}

\begin{abstract}
National Transport Policy (2019-2030) strives to improve the transportation sector towards a conducive and competitive sector while fulfils the demands of people. The new development of Mass Rapid Transit (MRT2) Sungai Buloh Subang - Putrajaya Line is expected to complete in 2022 and would benefit 529,000 users. This paper analyses the preferences of users on the facility provision at mass rapid transit stations in the local context. This paper was based on secondary and primary data sources such as official documents, websites and data collected for the Integrated MRT2 Land Use Masterplan. Document analysis method was employed to review official sources from public transport providers across selected benchmarked countries. Six categories of facility at mass rapid transit stations were evaluated using 40 criteria. Results suggested improvements are needed in barrier-free considerations and convenient facilities. Statistical analyses, involving descriptive and inferential analyses, were conducted. The results show that gender and travel time to station influenced users' preferences on facilities needed at stations. This paper suggests that certain criteria of facilities must be considered based on universal needs of the population to encourage usage of MRT2 as public transport as well as to provide convenient travel experiences.
\end{abstract}

Keywords: MRT2, mass rapid transit station, public facility, perception study

\footnotetext{
${ }^{1}$ Master Student. Email: azizan.ainina@yahoo.com
} 
PLANNING MALAYSIA

Journal of the Malaysia Institute of Planners (2021)

\section{INTRODUCTION}

The development of mass rapid transit in cities is expected to improve the economic state of urban areas in terms of productivity, social and quality of life. Mass Rapid Transit (MRT) development is aimed to encourage the use of public transport and to reduce dependence on private vehicles, hence will minimise environmental pollution (Basagaña, Triguero-Mas, Agis, Pérez, Reche, Alastuey, \& Querol, 2018; Gao, Yu, Wang, \& Vejre, 2019). MRT also allows adjacent cities and towns to benefit from urban agglomeration that offers exchange of knowledge, services and manpower. Additionally, it helps to boost the services sector such as logistics, education, health, tourism, industry and agriculture.

As the growth of Kuala Lumpur conurbation expands, Klang Valley's challenges are to provide sustainable transport infrastructure and public transport facilities. Arterial roads in cities are unable to accommodate the high number of vehicles, particularly during peak hours. Traffic congestion and poor public transport network will affect the transportation system between urban and suburban region. Studies have found that daily commuters with health issues prefer to use public transport, however on average, private vehicle users are willing to pay more for cars rather than to rely on public transport (Bazrbachi, Sidique, Shamsudin, Radam, Kaffashi, \& Adam, 2017). Other studies have shown that price changes for car fuel and public transport fares did not inclusively affect commuting behaviours (Abdulrazzaq, Abdulkareem, Yazid, Borhan, \& Mahdi, 2020). Additionally, deficiency of facilities at public transport stations and the difficulty of access between commuters' origins and destinations using public transport also influence commuters' decisions to commute using private vehicles (Yusoff, Safian, Bilal, \& Yassin, 2019).

\section{RESEARCH BACKGROUND}

There are multiple terminologies used referring to the rapid transit system across the globe. American Public Transit Association (1994, p.23) defines heavy rail as "an electric railway with the capacity for a 'heavy volume' of traffic and characterized by exclusive rights-of-way, multi-car trains, high speed and rapid acceleration, sophisticated signalling and high platform loading. Also known as 'rapid rail', 'subway', elevated railway' or 'metropolitan railway'. Table 1 shows the overview of rapid transit providers for MRT SBK Line, Taipei MRT, Osaka Metro, Sydney Metro and London Underground. 
Ainina Azizan, Mariana Mohamed Osman, Noor Suzilawati Rabe, Nuranisa Huda Ramlan, Nurul Ardila Azmi, Suraya Amiruddin

Users' Preferences on the Provision of Facilities for Mass Rapid Transit Sungai Buloh - Subang - Putrajaya Line (MRT2) Stations

Table 1: Overview of Rapid Transit Providers in Local and Global Context

\begin{tabular}{|c|c|c|c|c|c|}
\hline & Malaysia & Taiwan & Japan & Australia & UK \\
\hline Provider & MRT Corp. & $\begin{array}{l}\text { Taipei Rapid } \\
\text { Transit Corp. }\end{array}$ & $\begin{array}{l}\text { Osaka Metro } \\
\text { Corp. Ltd. }\end{array}$ & $\begin{array}{l}\text { Metro Trains } \\
\text { Sydney }\end{array}$ & $\begin{array}{l}\text { London } \\
\text { Underground } \\
\text { Ltd. }\end{array}$ \\
\hline Area & $\begin{array}{l}\text { Sg. Buloh - } \\
\text { Kajang } \\
\text { (SBK), } \\
\text { Klang Valley }\end{array}$ & $\begin{array}{l}\text { Taipei } \\
\text { Metropolitan }\end{array}$ & $\begin{array}{l}\text { Osaka } \\
\text { Metropolitan }\end{array}$ & $\begin{array}{l}\text { Sydney } \\
\text { Metro City } \\
\text { \& Southwest }\end{array}$ & $\begin{array}{l}\text { Greater } \\
\text { London, } \\
\text { Buckingham } \\
\text { shire, Essex } \\
\& \\
\text { Hertfordshire }\end{array}$ \\
\hline Track length & $52.2 \mathrm{~km}$ & $152.9 \mathrm{~km}$ & $129.9 \mathrm{~km}$ & $66 \mathrm{~km}$ & $402 \mathrm{~km}$ \\
\hline No. of station & 31 station & 108 station & 133 station & 31 station & 270 station \\
\hline Daily ridership & 175,213 & $2,163,000$ & $2,452,000$ & 37,909 & $5,000,000$ \\
\hline $\begin{array}{l}\text { Operation } \\
\text { year }\end{array}$ & 2017 & 1996 & 1933 & 2019 & 1863 \\
\hline
\end{tabular}

On $16^{\text {th }}$ December 2016, Mass Rapid Transit (MRT) Sungai Buloh Kajang Line or also introduced as MRT1 Kajang Line is officially operating in Malaysia spanning across 31 stations between Sungai Buloh and Kajang, and recorded an average daily ridership of 175,213 riders. MRT Sungai Buloh Serdang - Putrajaya Line or MRT2 Putrajaya Line is the second of the three planned MRT routes by MRT Corporation after MRT1 Kajang Line. While the MRT2 Putrajaya Line is under construction, this paper aims to determine the facilities needed at the new stations based on analysis on users' preferences and current provision of facilities at MRT1 Kajang Line.

MRT2 Putrajaya Line is part of the development of inclusive metro rail transportation system focuses to expand the networks in densely populated and developed areas, and to reduce the dependence on private vehicles (Mass Rapid Transit Corporation, 2017). The development of MRT2 Putrajaya Line is planned along a $52.2 \mathrm{~km}$ route that includes $38.7 \mathrm{~km}$ elevated track and $13.5 \mathrm{~km}$ underground track. This line has 36 stations with three committed stations, out of which 25 will be elevated stations and 11 will be underground stations. The line spans across five local authorities (LA) that are Petaling Jaya Municipal Council (MBPJ), Kuala Lumpur City Hall (DBKL), Subang Jaya City Council (MBSJ), Sepang Municipal Council (MPSp), Perbadanan Putrajaya (PPj). One LA that is Selayang Municipal Council (MPS) is located within the Zone of Influence (ZOI) of MRT2 Putrajaya Line development. There are 4 stations in MPBJ area, 21 stations in DBKL area, 7 stations in MPSJ area, 3 stations in MPSp area and 1 station in PPj area. 
The development of complete and well-circulated train stations is among the main criteria of efficient operation of the transport system. They ensure passengers' convenience and safe travel (Yusoff et. al, 2019; Bachok, 2010). Scholars have found that improving the level of service (Ramos, Vicente, Passos, Costa, \& Reis, 2019) and facilities of stations (Susanti, Soemitro, \& Suprayitno, 2019) can engage daily commuters to utilise urban railway service. Furthermore, constantly maintained and occasionally upgraded stations can also encourage commuters to shift from driving to transits (Khattak, Jiang, Zhu, \& $\mathrm{Hu}, 2017)$. Meanwhile, Loukaitou-Sideris and Peters (2017) suggest that station spatial connectivity (pedestrian connections, wayfinding strategies \& outdoorindoor communal space), intermodal connectivity (interchange transport terminal, bike parking \& storage lockers) and operational connectivity (coordination among agencies and public transport providers) are other key factors of a successful transport system.

Perception plays a great role in determining travellers' motivation and confidence to visit an area (Khan, Chelliah, \& Ahmed, 2017). Negative perception of certain attributes such as risks, safety and constraints could deter an individual from visiting a particular place. To form a perception, an individual will collect, choose, arrange and transmit information regarding the place (Bachok, Osman, Khalid, \& Ibrahim, 2013). Furthermore, Kadir et al. (2020) added that other important aspects that describe perception are satisfaction, expectation and experience of an individual. Thus, perception evaluation is a great tool that can be employed to assist service providers in identifying the relevant services or products to provide or the quality of those services and products being provided (Tukamushaba, Xiao, \& Ladkin, 2016).

\section{RESEARCH METHODOLOGY}

This paper analyses secondary and primary data from multiple documents and perception questionnaire survey from a study for MRT2 Putrajaya Line Land Use Masterplan using multiple methods of document analysis, descriptive analysis and inferential analysis. Document analysis is the interpretation information from written documents or materials related to a subject matter (Ay \& Zeynep, 2019). To conduct the document analysis, several official documents and information were gathered from public transportation providers particularly for mass rapid transit from Malaysia, Taiwan, Japan, Australia and the United Kingdom. The documents were reviewed using inductive approach where six themes or categories were generated throughout the process. From the data collected, the correlation between selected countries and facility categories were tabulated. Additionally, multiple descriptive and inferential analyses were also undertaken using the primary data from the questionnaire survey which was conducted among the potential users of MRT2 Putrajaya Line. 
Ainina Azizan, Mariana Mohamed Osman, Noor Suzilawati Rabe, Nuranisa Huda Ramlan, Nurul Ardila Azmi, Suraya Amiruddin

Users' Preferences on the Provision of Facilities for Mass Rapid Transit Sungai Buloh - Subang - Putrajaya

Line (MRT2) Stations

\section{FINDINGS AND DISCUSSION}

This section discusses the results from the document analysis on facilities at MRT stations in the global and local context, as well as the results from the primary data analyses.

\section{Evaluation of Mass Rapid Transit Stations Facilities}

The discussion begins with the comparative method employed to identify and categorise the facilities provided at rapid transit stations for MRT1 Sungai BulohKajang Line (Malaysia), Taipei Metro (Taiwan), Osaka Metro (Japan), Sydney Metro (Australia) and London Underground (United Kingdom).

Table 2: Criteria Matrix Table

\begin{tabular}{|c|c|c|c|c|c|c|c|}
\hline Category & No. & Criteria & $\frac{\sqrt[\pi]{\pi}}{\sum_{\pi}^{\frac{\pi}{\sigma}}}$ & 矛 & 离 & 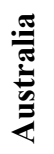 & 光 \\
\hline \multirow{8}{*}{$\begin{array}{l}\text { Safety and } \\
\text { security }\end{array}$} & 1 & Platform screen doors & $x$ & 0 & 0 & $\circ$ & $\circ$ \\
\hline & 2 & CCTV surveillance & o & o & $\circ$ & $\circ$ & $\circ$ \\
\hline & 3 & Emergency intercoms & o & 0 & $\circ$ & 0 & $\circ$ \\
\hline & 4 & Good lighting & o & o & $\circ$ & 0 & $\circ$ \\
\hline & 5 & Handy safety guide & $x$ & $x$ & $\circ$ & $\mathrm{x}$ & $x$ \\
\hline & 6 & Automatic external defibrillators (AEDs) & $\mathrm{x}$ & 0 & 0 & $\mathrm{x}$ & $\circ$ \\
\hline & 7 & Disaster prevention monitoring & $x$ & $x$ & 0 & $x$ & $x$ \\
\hline & 8 & CPTED pedestrian infrastructure & o & o & $\circ$ & $\circ$ & $\circ$ \\
\hline \multirow{2}{*}{ Information } & 9 & Wayfinding signage & 0 & 0 & $\circ$ & $\circ$ & $\circ$ \\
\hline & 10 & Sound broadcast & 0 & $\circ$ & $\circ$ & $\circ$ & $\circ$ \\
\hline \multirow{12}{*}{$\begin{array}{l}\text { Barrier-free } \\
\text { facility }\end{array}$} & 11 & Ticket gate & 0 & 0 & 0 & $\circ$ & $\circ$ \\
\hline & 12 & Tactile for visually impaired & 0 & 0 & $\circ$ & $\circ$ & $\circ$ \\
\hline & 13 & Guidance system & 0 & $\circ$ & $\circ$ & $\circ$ & $\circ$ \\
\hline & 14 & Vertical transport & 0 & 0 & $\circ$ & $\circ$ & $\circ$ \\
\hline & 15 & Ticket machine/counter & o & 0 & $\circ$ & 0 & $\circ$ \\
\hline & 16 & Toilet & 0 & 0 & 0 & 0 & $\circ$ \\
\hline & 17 & Rail ramp & $x$ & 0 & 0 & 0 & $\circ$ \\
\hline & 18 & Taxi service for PWD & $x$ & 0 & $x$ & 0 & $\circ$ \\
\hline & 19 & Hearing loop system & $x$ & $x$ & $x$ & 0 & $\circ$ \\
\hline & 20 & Accessible-friendly handrail & $\mathrm{x}$ & 0 & $\circ$ & 0 & $\circ$ \\
\hline & 21 & Audio announcement & 0 & 0 & 0 & 0 & $\circ$ \\
\hline & 22 & Wheelchair rental & $x$ & 0 & 0 & $x$ & $x$ \\
\hline \multirow{5}{*}{$\begin{array}{l}\text { Convenient } \\
\text { facility }\end{array}$} & 23 & Worship facility & o & $\mathbf{x}$ & $x$ & $\mathrm{x}$ & $x$ \\
\hline & 24 & Public toilet & 0 & 0 & $\circ$ & 0 & $\circ$ \\
\hline & 25 & Children toilet facility & $x$ & 0 & 0 & 0 & $\circ$ \\
\hline & 26 & Baby care room & $\mathrm{x}$ & 0 & $\circ$ & $\mathrm{x}$ & $x$ \\
\hline & 27 & Storage locker & $x$ & 0 & 0 & 0 & $x$ \\
\hline
\end{tabular}


PLANNING MALAYSIA

Journal of the Malaysia Institute of Planners (2021)

\begin{tabular}{|c|c|c|c|c|c|c|c|}
\hline & 28 & Refreshment facility & 0 & 0 & 0 & $\circ$ & 0 \\
\hline & 29 & Shaded waiting area/meeting point & o & o & o & o & $\circ$ \\
\hline \multirow{9}{*}{ Accessibility } & 30 & Park N Ride & 0 & 0 & 0 & 0 & 0 \\
\hline & 31 & Transport interchange & o & 0 & $\circ$ & $\circ$ & $\circ$ \\
\hline & 32 & Pedestrian infrastructure & o & $\circ$ & 0 & 0 & 0 \\
\hline & 33 & Bicycle parking & 0 & 0 & 0 & 0 & $\circ$ \\
\hline & 34 & Bicycle storage & $x$ & $x$ & $x$ & 0 & 0 \\
\hline & 35 & Bicycle hire service & $x$ & o & 0 & 0 & 0 \\
\hline & 36 & Car parking & 0 & 0 & 0 & o & 0 \\
\hline & 37 & Bicycle infrastructure & o & o & 0 & 0 & 0 \\
\hline & 38 & Taxi stand and drop-off point & 0 & 0 & o & 0 & 0 \\
\hline \multirow{2}{*}{$\begin{array}{l}\text { General } \\
\text { service }\end{array}$} & 39 & Lost property office & $x$ & 0 & 0 & 0 & 0 \\
\hline & 40 & Free Wi-Fi & $x$ & $\circ$ & $x$ & $x$ & 0 \\
\hline
\end{tabular}

As shown in Table 2, 40 criteria were identified under six facility categories namely Safety and Security, Information, Barrier-free Facility, Convenient Facility, Accessibility and General Service. It was found that under Safety and Security category, all selected service providers operate stations equipped with CCTV surveillance, emergency intercoms, and good lighting as well as adopted CPTED principles in the design of pedestrian infrastructure. In addition, it can be seen that safety and security received greater attention in Osaka Metro stations where handy safety guide was provided and disaster prevention monitoring system was put in place. The extra precautions maybe due to the geographical location factor of the country where the likelihood for an earthquake to happen is great.

Information and Accessibility facilities are also well-provided at the at the stations operated by the service providers. These include signage, public broadcast, park and ride, transport interchange, and bicycle and pedestrian infrastructure.

Facilities related to Barrier-free category are also comprehensively provided by majority of the service providers. However, for stations under the the MRT1 Kajang Line, further improvement is required especially with regard to the provision of handrail, taxi service for person-with-disability (PWD), hearing loop system and wheelchair rental.

Similarly, stations under MRT1 Kajang Line also lacking in terms of Convenient facilities, where children toilet facility, baby care room and storage locker are not provided on site. However, these stations offer worship facility (prayer room) while others do not.

Users' Perception of Facilities Needed at MRT2 Sungai Buloh - Subang Putrajaya Line Stations 
Ainina Azizan, Mariana Mohamed Osman, Noor Suzilawati Rabe, Nuranisa Huda Ramlan, Nurul Ardila Azmi, Suraya Amiruddin

Users' Preferences on the Provision of Facilities for Mass Rapid Transit Sungai Buloh - Subang - Putrajaya Line (MRT2) Stations

To obtain first hand perception of facilities needed for the MRT2 Putrajaya Line stations, a total of 580 potential users were surveyed, of which $53.4 \%$ were males and $46.6 \%$ were females (Table 3). $92.9 \%$ of the respondents agreed that they would potentially use the MRT2 Putrajaya Line stations once the line is up and running.

Table 3: Cross-tabulation between potential to use MRT2 with gender

\begin{tabular}{|c|c|c|c|c|c|c|}
\hline \multirow{2}{*}{$\begin{array}{l}\text { Potential to use } \\
\text { MRT2 }\end{array}$} & \multicolumn{2}{|c|}{ Male } & \multicolumn{2}{|c|}{ Female } & \multicolumn{2}{|c|}{ Total } \\
\hline & $\mathbf{F}$ & $\%$ & $\mathbf{F}$ & $\%$ & $\mathbf{F}$ & $\%$ \\
\hline Yes/Maybe & 288 & $93.5 \%$ & 251 & $92.3 \%$ & 539 & $92.9 \%$ \\
\hline No & 20 & $6.5 \%$ & 21 & $7.7 \%$ & 41 & $7.1 \%$ \\
\hline Total & 308 & 100.0 & 272 & 100.0 & 580 & 100 \\
\hline
\end{tabular}

In terms of travel time, majority of the respondents (79.9\%) will require less than 30 minutes to arrive at the stations from their origins (Table 4). Out of this, $40.2 \%$ of respondents will take less than 15 minutes to arrive at MRT2 Putrajaya Line stations from their origin and $39.7 \%$ will take between 15 to 30 minutes. Students $(47.62 \%)$ and visitors (40.9\%) made up the highest group with travel time to stations less than 15 minutes. Meanwhile, the group that will require 15 to 30 minutes travel time is dominated by employees $(40.7 \%)$, and entrepreneur and traders (40.7\%).

Table 4: Cross-tabulation between travel time to arrive to station by group

\begin{tabular}{|c|c|c|c|c|c|c|c|c|c|c|}
\hline \multirow[t]{2}{*}{ Travel time } & \multicolumn{2}{|c|}{$\begin{array}{c}\text { Entrepreneur } \\
\text { \& Traders }\end{array}$} & \multicolumn{2}{|c|}{ Employee } & \multicolumn{2}{|c|}{ Visitor } & \multicolumn{2}{|c|}{ Student } & \multicolumn{2}{|c|}{ Total } \\
\hline & $\mathbf{F}$ & $\%$ & $\mathbf{F}$ & $\%$ & $\mathbf{F}$ & $\%$ & $\mathbf{F}$ & $\%$ & $\mathbf{F}$ & $\%$ \\
\hline$<15$ mins & 52 & 38.5 & 92 & 39.8 & 79 & 40.9 & 10 & 47.62 & 233 & 40.2 \\
\hline $15-30$ mins & 55 & 40.7 & 94 & 40.7 & 73 & 37.8 & 8 & 38.10 & 230 & 39.7 \\
\hline $31-45$ mins & 18 & 13.3 & 30 & 13.0 & 22 & 11.4 & 3 & 14.29 & 73 & 12.6 \\
\hline $46-60$ mins & 6 & 4.4 & 13 & 5.6 & 9 & 4.7 & 0 & 0.00 & 28 & 4.8 \\
\hline $61-90$ mins & 0 & 0.0 & 0 & 0.0 & 1 & 0.5 & 0 & 0.00 & 1 & 0.2 \\
\hline$>90$ mins & 4 & 3.0 & 2 & 0.9 & 9 & 4.7 & 0 & 0.00 & 15 & 2.6 \\
\hline Total & 135 & 100.0 & 231 & 100.0 & 193 & 100.0 & 21 & 100 & 580 & 100.0 \\
\hline
\end{tabular}

Table 6 shows that most preferred 'outside station' facilities were car and motorcycle parking (91.9\%), shaded bus stop for intermediate-bus service (77.4\%) and shaded pedestrian walkway (73.0\%). Meanwhile, Table 8 shows most preferred 'inside station' facilities were CCTV surveillance (93.3\%), toilet 
(84.4\%) and vertical transport (80.8\%). $63.4 \%$ of respondents also suggested that barrier-free must be provided as part of the facilities needed inside station. This is in line with the earlier findings that improvements are required for MRT stations in Malaysia with regard to barrier-free facilities.

Table 5: Hypothesis of Chi-square test on perceptions of facilities needed outside station with gender and travel time to arrive station

\begin{tabular}{cl}
\hline Decision & \multicolumn{1}{c}{ Statement } \\
\hline $\mathbf{H}_{\mathbf{0}}$ & $\begin{array}{l}\text { Respondent's gender and travel time have no effect on their perceptions of } \\
\text { facilities needed outside station }\end{array}$ \\
\hline $\mathbf{H}_{\mathbf{1}}$ & $\begin{array}{l}\text { Respondent's gender and travel time have positive effect on their } \\
\text { perceptions of facilities needed outside station }\end{array}$ \\
\hline
\end{tabular}

Table 6: Chi-square test between perceptions of facilities needed outside station with gender and travel time to arrive station

\begin{tabular}{llccccc}
\hline \multirow{2}{*}{ Facility needed outside station } & \multicolumn{3}{c}{ Gender } & \multicolumn{4}{c}{ Travel time to station } \\
\cline { 2 - 7 } & Value & p-value & $\%$ & Value & p-value & $\%$ \\
\hline 1. Car and motorcycle parking & 47.044 & 0.000 & 0.0 & $\mathbf{0 . 2 0 7}$ & $\mathbf{0 . 1 4 7}$ & $\mathbf{0 . 0}$ \\
\hline 2. Bicycle parking & 341.733 & 0.000 & 0.0 & 340.506 & 0.000 & 0.0 \\
\hline $\begin{array}{l}\text { 3. Shaded bus stop for intermediate- } \\
\text { bus service }\end{array}$ & 34.177 & 0.000 & 0.0 & 11.694 & 0.000 & 0.0 \\
\hline 4. Taxi and e-hailing service parking & 117.265 & 0.000 & 0.0 & 106.503 & 0.000 & 0.0 \\
\hline 5. Wayfinding and signage & 50.941 & 0.000 & 0.0 & 38.414 & 0.000 & 0.0 \\
\hline 6. Shaded pedestrian walkway & 48.022 & 0.000 & 0.0 & 18.996 & 0.000 & 0.0 \\
\hline 7. Space for food vendors & 171.943 & 0.000 & 0.0 & 167.128 & 0.000 & 0.0 \\
\hline $\begin{array}{l}\text { 8. Food vendors and motorcycle } \\
\text { parking away from entrance }\end{array}$ & 293.603 & 0.000 & 0.0 & 289.333 & 0.000 & 0.0 \\
\hline $\begin{array}{l}\text { 9. Shaded waiting, meeting and } \\
\text { resting area }\end{array}$ & 90.554 & 0.000 & 0.0 & 79.662 & 0.000 & 0.0 \\
\hline $\begin{array}{l}\text { 10. Area for cultural activities } \\
\text { Note: \% }=\% \text { cell with count less than 5; for result to be valid, the\% must not be more than 20\% } \\
\text { Source: Author's calculation based on perception study for Integrated MRT2 Land Use Masterplan (2020) }\end{array}$
\end{tabular}

Inferential tests were run for facilities needed outside and inside station by using Chi-square test against gender and travel time to station. In Table 6 , all tested p-value for respondents' perceptions on facility needed outside station were less than 0.05 that stipulates the $\mathrm{H}_{0}$ can be rejected. Therefore, it can be concluded from Table 5 that respondents' gender influences their preferences for facility needed outside station.

The result of Chi-square for facility needed outside station and travel time to station shows that one tested p-value for car and motorcycle parking is more than 0.05 (Table 6). This indicates $\mathrm{H}_{0}$ cannot be rejected. Nevertheless, the 
Ainina Azizan, Mariana Mohamed Osman, Noor Suzilawati Rabe, Nuranisa Huda Ramlan, Nurul Ardila Azmi, Suraya Amiruddin

Users' Preferences on the Provision of Facilities for Mass Rapid Transit Sungai Buloh - Subang - Putrajaya Line (MRT2) Stations

other p-values for facility needed outside station with travel time to station were less than 0.05 , thus $\mathrm{H}_{0}$ can be rejected. In other words, this result shows that respondents' travel time to station influence their perceptions of facility needed outside station, except for car and motorcycle parking (0.147).

Table 7: Hypothesis of Chi-square test on perceptions of facilities needed inside station with gender and travel time to arrive station

\begin{tabular}{cl}
\hline Decision & \multicolumn{1}{c}{ Statement } \\
\hline $\mathbf{H}_{\mathbf{0}}$ & $\begin{array}{l}\text { Respondent's gender and travel time have no effect on their perceptions of } \\
\text { facilities needed inside station }\end{array}$ \\
\hline $\mathbf{H}_{\mathbf{1}}$ & $\begin{array}{l}\text { Respondent's gender and travel time have positive effect on their } \\
\text { perceptions of facilities needed inside station }\end{array}$ \\
\hline
\end{tabular}

Table 8: Chi-square test between perceptions on facilities needed inside station with gender and travel time to arrive station

\begin{tabular}{|c|c|c|c|c|c|c|}
\hline \multirow{2}{*}{ Facility needed inside station } & \multicolumn{3}{|c|}{ Gender } & \multicolumn{3}{|c|}{ Travel time to station } \\
\hline & Value & p-value & $\%$ & Value & p-value & $\%$ \\
\hline 1. Maintained and cleaned station & 30.936 & 0.000 & 0.0 & 0.498 & 0.024 & 0.0 \\
\hline 2. Seating area & 48.837 & 0.000 & 0.0 & 23.985 & 0.000 & 0.0 \\
\hline 3. Wayfinding and signage & 49.060 & 0.000 & 0.0 & 29.546 & 0.000 & 0.0 \\
\hline 4. Toilet facility & 31.023 & 0.000 & 0.0 & 0.621 & 0.012 & 0.0 \\
\hline 5. Barrier-free considerations & 42.299 & 0.000 & 0.0 & 15.990 & 0.000 & 0.0 \\
\hline 6. Refreshment facility & 164.651 & 0.000 & 0.0 & 158.608 & 0.000 & 0.0 \\
\hline 7. CCTV surveillance & 42.760 & 0.000 & 0.0 & 0.398 & 0.044 & 0.0 \\
\hline 8. Vertical transport & 32.269 & 0.000 & 0.0 & 4.469 & 0.000 & 0.0 \\
\hline 9. Emergency intercom & 117.164 & 0.000 & 0.0 & 111.527 & 0.000 & 0.0 \\
\hline
\end{tabular}

The Chi-square test shows for facilities inside station returns p-value of less than 0.05 for all relationships (Table 8). Referring to Table 7, null hypothesis is rejected, thus this indicates that respondents' gender and travel time to station influence their perceptions of facility needed inside station.

\section{RECOMMENDATIONS AND CONCLUSION}

This paper has identified the provision of facilities at MRT stations across selected countries and evaluated users' perceptions of facilities needed at MRT2 Putrajaya Line stations. The findings show that MRT stations in Malaysia can be improved in terms of Barrier-free and Convenient facilities. Comparative analysis shows that local stations experience deficiencies in the provision of rail ramp, taxi service for PWD, hearing loop system, accessible-friendly handrail and wheelchair rental. Similarly, children toilet, baby care room and storage locker 
are also not provided. Current MRT stations in Malaysia also lack platform screen doors, bicycle storage and hire services, and lost property office.

In terms of perceptions, Chi-test square results showed respondents' gender and travel time influence their perceptions of facility needed outside station, except for car and motorcycle parking facilities. Therefore, to cater the gender preference, concerns on safety and security measure such as CCTV surveillance and separated pedestrian walkway should be emphasised. Design of stations and facilities inside and outside of the stations must also reduce the safety risks to users, especially female users. In terms of travel time, provision of refreshment facilities, waiting and meeting area should be considered.

In conclusion, this paper has provided insights on the criteria of the facilities to be improved and factors to be considered upon in determining the type of facilities to be provided at MRT2 Putrajaya Line stations. The findings from this study can be implemented in order to encourage travellers to opt for MRT2 Putrajaya Line as the main mode of transport other than providing convenience to the travellers. It is recommended that future research further identify MRT2 Putrajaya Line group of users and their travel purpose to best facilitate travellers' need with particular facilities at MRT2 Putrajaya Line stations.

\section{ACKNOWLEDGEMENT}

The authors would like to extend their appreciations to IIUM and Ministry of Higher Education. This research was supported in part by Fundamental Research

Grant Scheme, Ministry of Higher Education, Malaysia (FRGS/1/2019/TK08/UIAM/02/1).

\section{REFERENCES}

Abdulrazzaq, L. R., Abdulkareem, M. N., Yazid, M. R. M., Borhan, M. N., \& Mahdi, M. S. (2020). Traffic congestion: Shift from private car to public transportation. Civil Engineering Journal, 6(8), 1547-1554.

American Public Transit Association. (1994). Glossary of transit terminology. n.p.: n.p.

Ay, T. S., \& Zeynep, Ö. (2019). An analysis of the documentary entitled talisman of the city as a teaching tool in the values education. Review of International Geographical Education Online, 9(3), 639-662.

Bachok, S. (2010) Behavioural Impacts of Integrated Public Transport Information System, unpublished PhD Thesis, University of South Australia, 2010, Adelaide.

Bachok, S., Osman, M. M., Khalid, U. A., \& Ibrahim, M. (2013). Commuters perceptions on rail based public transport services: A case study of KTM Komuter in Kuala Lumpur City, Malaysia. Planning Malaysia, 11(3).

Basagaña, X., Triguero-Mas, M., Agis, D., Pérez, N., Reche, C., Alastuey, A., \& Querol, X. (2018). Effect of public transport strikes on air pollution levels in Barcelona (Spain). Science of the Total Environment, 610, 1076-1082. 
Ainina Azizan, Mariana Mohamed Osman, Noor Suzilawati Rabe, Nuranisa Huda Ramlan, Nurul Ardila Azmi, Suraya Amiruddin

Users' Preferences on the Provision of Facilities for Mass Rapid Transit Sungai Buloh - Subang - Putrajaya Line (MRT2) Stations

Bazrbachi, A., Sidique, S. F., Shamsudin, M. N., Radam, A., Kaffashi, S., \& Adam, S. U. (2017). Willingness to pay to improve air quality: A study of private vehicle owners in Klang Valley, Malaysia. Journal of Cleaner Production, 148, 73-83.

Gao, J., Yu, Z., Wang, L., \& Vejre, H. (2019). Suitability of regional development based on ecosystem service benefits and losses: A case study of the Yangtze River Delta urban agglomeration, China. Ecological Indicators, 107, 105579.

Kadir, N. A. A., Mohamad, M. R., Olabayonle, O. A., Zahari, M. Z. M., Bachok, S., \& Osman, M. M. (2020). Travellers' perception of worship facilities for multimodal users of MRT SBK Line. PLANNING MALAYSIA Journal of the Malaysian Institute of Planner, 18(14).

Khan, M. J., Chelliah, S., \& Ahmed, S. (2017). Factors influencing destination image and visit intention among young women travellers: Role of travel motivation, perceived risks, and travel constraints. Asia Pacific Journal of Tourism Research, 22(11), 1139-1155.

Khattak, A., Jiang, Y., Zhu, J., \& Hu, L. (2017). A new simulation-optimization approach for the circulation facilities design at urban rail transit station. Archives of Transport, 43.

Loukaitou-Sideris, A., \& Peters, D. (2017). A comparative analysis of high-speed rail station development into destination and/or multi-use facilities: The case of San Jose Diridon (No. CA-17-2969). Mineta Transportation Institute.

Mass Rapid Transit Corporation. (2017). MRT Corp Sdn. Bhd. | Corporate Profile. MRT Corp. Retrieved February 15, 2021, from https://www.mymrt.com. my/corporate/mrt-corp/

Office of Rail and Road. (2014, December 19). An overview of the British rail industry. https://www.orr.gov.uk/media/12376.

Osaka Municipal Transportation Bureau. (2017, September). Osaka Municipal Transportation Bureau | About the budget and settlement of accounts of the Transportation Bureau. Retrieved from: https://web.archive.org/web/ 20170916211227/www.kotsu.city.osaka.lg.jp/business/management/financial/yo san_kessan.html References You have no saved citations.

Prasarana Malaysia Berhad (2019). Bilangan Penumpang bagi Perkhidmatan Pengangkutan Rel. https://web.archive.org/web/20200422202615/http://www. mot.gov.my/en/Statistik\%20Rel/2019\%204\%20-\%20SUKU\%20IV\%202019/ Jadual\%202.9\%20Q4\%202019.pdf

Ramos, S., Vicente, P., Passos, A. M., Costa, P., \& Reis, E. (2019). Perceptions of the public transport service as a barrier to the adoption of public transport: A qualitative study. Social Sciences, 8(5), 150.

Susanti, A., Soemitro, R. A. A., \& Suprayitno, H. (2019). Planning for facility needs in train station based on comparison of connecting modes usage. International Journal of Civil Engineering and Technology (IJCIET), 10, 239-248.

Transport for London (2021). About Transport for London (TfL). https://tfl.gov.uk/corporate/about-tfl/what-we-do\#on-this-page-1

Taipei Rapid Transit Corporation. (2020, September). Taipei Rapid Transit Corporation Annual Report 2019. Retrieved from: https://www-ws. gov.taipei/001/Upload /405/relfile/18288/7592/8c6c8811-f50a-402a-b961-c23067fba50c.pdf 
Transport Performance and Analytics (TPA) (2019, May 16). Transport for NSW. Metro patronage. https://www.transport.nsw.gov.au/data-and-research / passengertravel/metro-patronage

Tukamushaba, E.K., Xiao, H. and Ladkin, A. (2016). The effect of tourists' perceptions of a tourism product on memorable travel experience: Implications for destination branding. European Journal of Tourism, Hospitality and Recreation (EJTHR), Vol.7, (No. 1): 2-12.

Yusoff, H. M., Safian, E.E., Bilal, K. \& Yassin, A. (2019). The criteria of railway station in Malaysia: A review of issues in facilities improvement. Science International. (Lahore), 31(2), 283-287.

Received: $15^{\text {th }}$ February 2021. Accepted: $7^{\text {th }}$ May 2021 